\title{
BEHAVIOR OF COMBINATION OF COCONUT FIBER AND RECRON FIBER IN CONCRETE
}

\author{
Harish Kumar ${ }^{1}$, S.Anandh ${ }^{2}$ \\ ${ }^{1}$ Student, Construction Engineering and Management, SRM University, Tamil Nadu, India \\ ${ }^{2}$ Assistent Professor, Construction Engineering and Management, SRM University, Tamil Nadu, India
}

\begin{abstract}
Concrete is strong in compression, as aggregate efficiently carries the compression load. However, it is weak in tension as the cement holding the aggregate in place can crack, allowing the structure to fail. This weakness had been adjusted over many decades by using a system of reinforcing bars (rebar) to create reinforced concrete; so that concrete primarily resists compressive stresses and rebar resist tensile and shear stresses and rebar resist tensile and shear stresses. It has been recognised that addition of small, closely spaced and uniformly distributed fibres to concrete would act as a crack arrester and would significantly improve the its static and dynamic properties
\end{abstract}

Keywords: fibre, shear stresses, rebar, concrete

\section{INTRODUCTION}

Fibre reinforced concrete can be defined as composite material consisting of mixture of cement, mortar or concrete and discontinuous, discrete, uniformly dispersed suitable fibres. The use of randomly oriented, short fibres to improve the physical properties of a matrix in an ancient concept. For example, fibres made of straw or jute has been used to improve the properties of bricks for thousands of years. Natural fibres are made from plant, animal and mineral sources. The most used natural fibres are cotton., bamboo and coconut. Metallic fibres are made of either steel or stainless steel. Polymer fibres are subset of man-made fibres, which are based on synthetic chemicals rather than arising natural fibres by purely physical process. Fibre reinforced concrete is increasingly used because of the advantage of increased static and dynamic tensile strength, energy absorbing characteristics and enhanced fatigue strength. The uniformly dispersal of fibres through the concrete provides isotropic properties not common to traditional reinforced concrete. Fibre reinforced concrete has been tried on overlays of air-field, road pavements, industrial floorings, bridge decks, channel lining, explosive resistant structures.

The following are the factors affecting the properties of FRC. The properties of FRC would obviously depend upon the efficient transfer of stress between matrix and fibres, which largely dependent on the

- $\quad$ Type of fibre used

- Orientation of fibre

- $\quad$ Fibre geometry

Recron is a state of art reinforcing material which is used to increase strength in a variety of applications like automotive battery, paper, infiltration fabrics and for improving the quality of construction.
Coconut fibre is extracted from the outer shell of coconut. These fibres are mostly used in products such as floor mats, doormats

\subsection{Objective}

- To determine the strength of fibre concrete

- To compare the strength of the conventional concrete, coconut fibre and recron fibre concrete

- To do plastering using recron fibre and to reduce the size of the roof slab, beams and columns

\subsection{Scope}

- $\quad$ Fibres can be used precast flyover

- Replacing fibres in construction

- Crack should be arrested during hydration

- $\quad$ Fibres are used for airport pavements

\subsection{Mix Design}

Table 2 Mix design

\begin{tabular}{|l|l|l|l|}
\hline $\begin{array}{l}\text { Water } \\
\text { cement } \\
\text { ratio (lit) }\end{array}$ & $\begin{array}{l}\text { Cement } \\
\text { content }(\mathrm{kg})\end{array}$ & $\begin{array}{l}\text { Fine } \\
\text { aggregate } \\
\text { content }(\mathrm{kg})\end{array}$ & $\begin{array}{l}\text { Coarse } \\
\text { aggregate } \\
\text { content }(\mathrm{kg})\end{array}$ \\
\hline 212.12 & 406.0 & 624.14 & 1032.27 \\
\hline 0.52 & 1 & 1.537 & 2.542 \\
\hline
\end{tabular}

The various materials used in this project work are shown in the table 3 below

\subsection{Material Properties}

Table 3 Properties of materials used

\begin{tabular}{|l|l|l|}
\hline S.No & Description & Parameter \\
\hline 1 & Grade of concrete & M20 \\
\hline 2 & cement & $\begin{array}{l}\text { OPC 53 grade IS 269- } \\
1976\end{array}$ \\
\hline
\end{tabular}




\begin{tabular}{|l|l|l|}
\hline 3 & Fine aggregate & $\begin{array}{l}\text { Sand conforming to zone } \\
\text { II of IS 383-1978 }\end{array}$ \\
\hline 4 & Coarse aggregate & $10-12 \mathrm{~mm}$ nominal size \\
\hline 5 & $\begin{array}{l}\text { Type and shape } \\
\text { of CA }\end{array}$ & Angular \\
\hline 6 & w/c ratio & 0.52 \\
\hline 7 & Steel fiber & $\begin{array}{l}\text { Undulated (0.6mm dia } \\
\text { and 36mm length ) }\end{array}$ \\
\hline 8 & $\begin{array}{l}\text { Polypropylene } \\
\text { fiber }\end{array}$ & $\begin{array}{l}\text { Bar chip fibers (42mm } \\
\text { length) }\end{array}$ \\
\hline 9 & Age of curing & $\begin{array}{l}7 \text { days, 14 days and 28 } \\
\text { days }\end{array}$ \\
\hline
\end{tabular}

\section{RESULTS AND DISCUSSION}

\subsection{Test Results for Compressive Strength}

The coconut fibre and recron fibre are mixed with PCC in different fibre volume to cast cubes and the fibre volume showing average compressive strength. The test results shows the 7, 14, 28 days compressive strength of coconut fibre, recron fibre and mixed with PCC. From the results increase in strength has been obtained in hybrid fibre in 28 days. The decrease in strength had been obtained in coconut fibre in 28 days

Table 4 Test results of compressive strength (7, 14 and 28

\begin{tabular}{|l|l|l|l|}
\hline \multirow{5}{*}{ Type of fibre } & No.of days & $\begin{array}{l}\text { Compressive strength in } \\
\text { N/mm }\end{array}$ \\
\cline { 3 - 4 } & & \multicolumn{2}{l}{} \\
\cline { 3 - 4 } & & Fibre percentage \\
\cline { 2 - 4 } Coconut fibre & 7 days & 16.42 & 17.67 \\
\cline { 2 - 4 } & 14 days & 18.06 & 19.49 \\
\cline { 2 - 4 } & 28 days & 20.17 & 20.80 \\
\hline \multirow{4}{*}{ Recron fibre } & 7 days & 16.67 & 18.67 \\
\cline { 2 - 4 } & 14 days & 18.49 & 21.49 \\
\cline { 2 - 4 } & 28 days & 20.24 & 23.56 \\
\hline \multirow{3}{*}{ Hybrid fibre } & 7 days & 16.48 & 18.57 \\
\cline { 2 - 4 } & 14 days & 20.11 & 22.85 \\
\cline { 2 - 4 } & 28 days & 21.08 & 24.24 \\
\hline
\end{tabular}

Table 5 Test results of tensile strength (7,14 and 28 days )

\begin{tabular}{|l|l|l|l|}
\hline Type of fibre & No.of days & \multicolumn{2}{|l|}{$\begin{array}{l}\text { Split tensile strength } \\
\text { in N/mm }\end{array}$} \\
\cline { 3 - 4 } & & \multicolumn{2}{|l|}{ Fibre percentage } \\
\cline { 3 - 4 } & & 0.5 & 1.0 \\
\hline \multirow{3}{*}{ Coconut fibre } & 7 days & 1.66 & 1.65 \\
\cline { 3 - 4 } & 14 days & 2.26 & 2.74 \\
\cline { 2 - 4 } & 28 days & 2.61 & 3.19 \\
\hline \multirow{3}{*}{ Recron fibre } & 7 days & 1.58 & 2.09 \\
\cline { 2 - 4 } & 14 days & 2.43 & 2.85 \\
\cline { 2 - 4 } & 28 days & 2.83 & 3.17 \\
\hline \multirow{3}{*}{ Hybrid fibre } & 7 days & 1.74 & 1.81 \\
\cline { 2 - 4 } & 14 days & 2.67 & 2.78 \\
\cline { 2 - 4 } & 28 days & 3.1 & 3.23 \\
\hline
\end{tabular}

Table 6 Test results of flexural strength (7, 14 and 28 days )

\begin{tabular}{|l|l|l|l|}
\hline Type of fibre & \multirow{2}{*}{ No.of days } & \multicolumn{2}{|l|}{$\begin{array}{l}\text { Split tensile strength } \\
\text { in N/mm }\end{array}$} \\
\cline { 3 - 4 } & & \multicolumn{2}{|l|}{ Fibre percentage } \\
\cline { 3 - 4 } & & 0.5 & 1.0 \\
\hline \multirow{4}{*}{ Coconut fibre } & 7 days & 2.02 & 2.10 \\
\cline { 2 - 4 } & 14 days & 2.52 & 3.48 \\
\cline { 2 - 4 } & 28 days & 2.83 & 4.06 \\
\hline \multirow{3}{*}{ Recron fibre } & 7 days & 1.86 & 2.35 \\
\cline { 2 - 4 } & 14 days & 2.86 & 3.15 \\
\cline { 2 - 4 } & 28 days & 3.33 & 3.94 \\
\hline \multirow{3}{*}{ Hybrid fibre } & 7 days & 2.07 & 2.31 \\
\cline { 2 - 4 } & 14 days & 3.18 & 3.54 \\
\cline { 2 - 4 } & 28 days & 3.7 & 4.12 \\
\hline
\end{tabular}

The FRC cubes with fibre volume of $1 \%$ achieved maximum flexural strength for coconut fibre, recon fibre and hybrid fibre respectively. Henceforth, for further studies in strength behaviour of beam $1 \%$ fibre volume will be used. The flexural strength represents the highest stress experienced within the material at its moment of rupture. The flexural strength would be the same as the tensile strength if the material were homogenous.

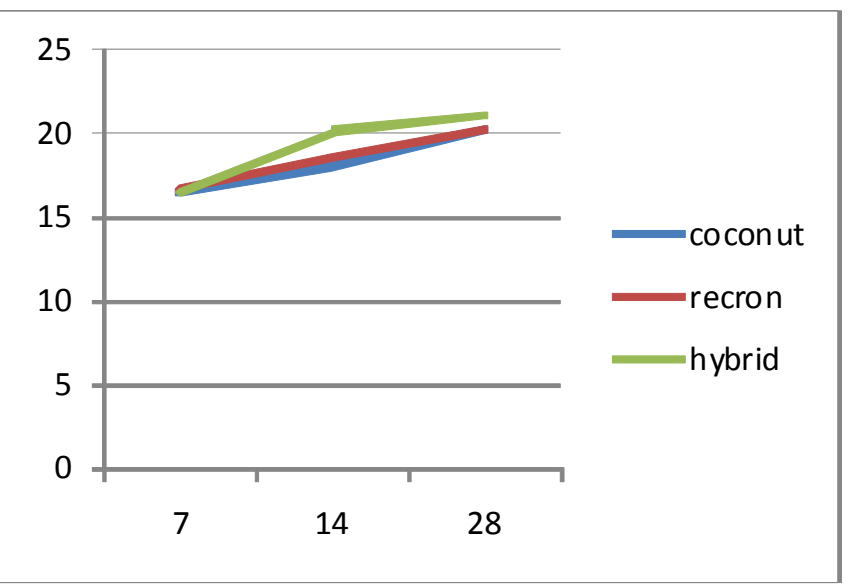

Fig 1 Compressive strength of $0.5 \%$ mixed coconut, recron \& hybrid fibre

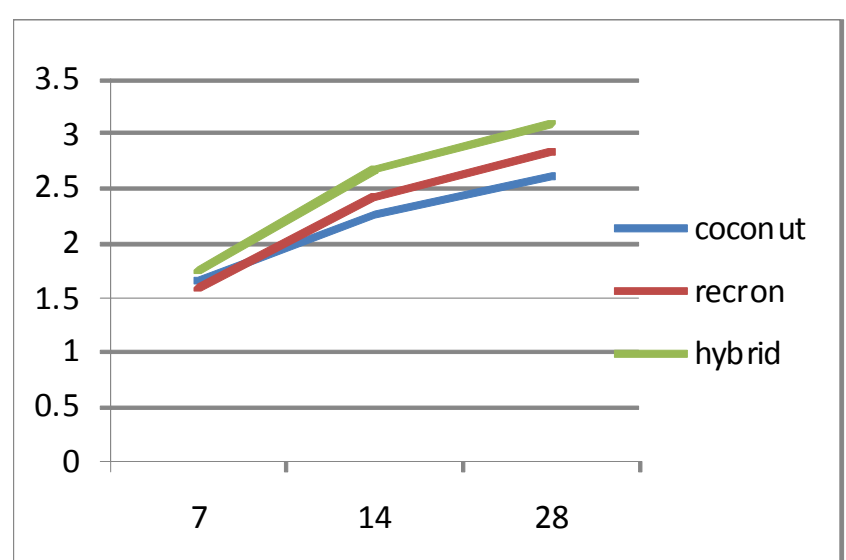

Fig 2 Split tensile strength of $0.5 \%$ mixed coconut, recron \& hybrid fibre 


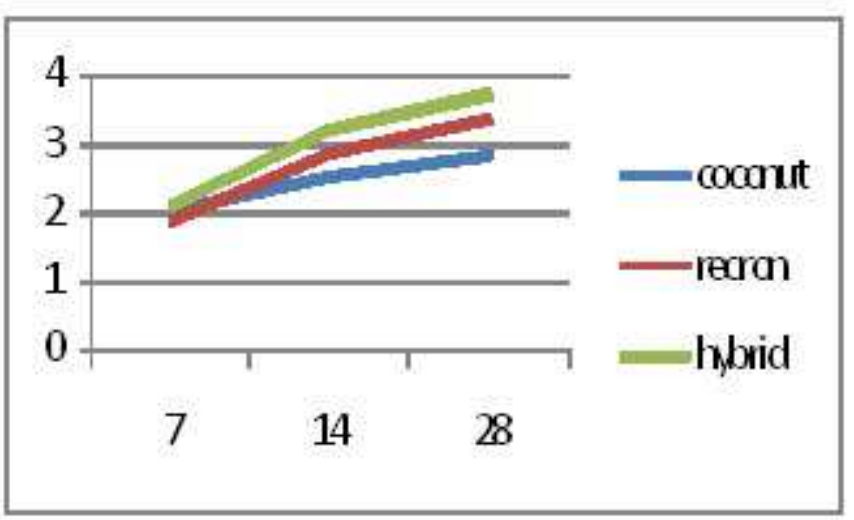

Fig 3 Flexural strength of $0.5 \%$ mixed coconut, recron \& hybrid fibre

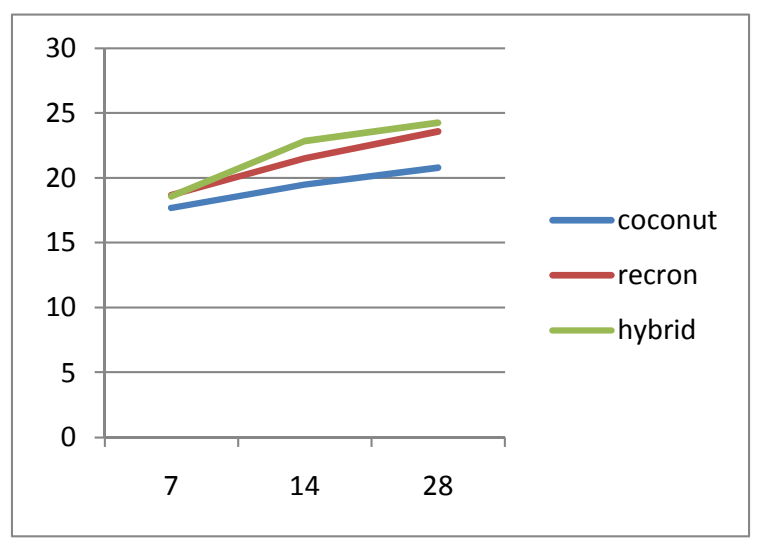

Fig 4 Compressive strength of $1 \%$ mixed coconut, recron \& hybrid fibre

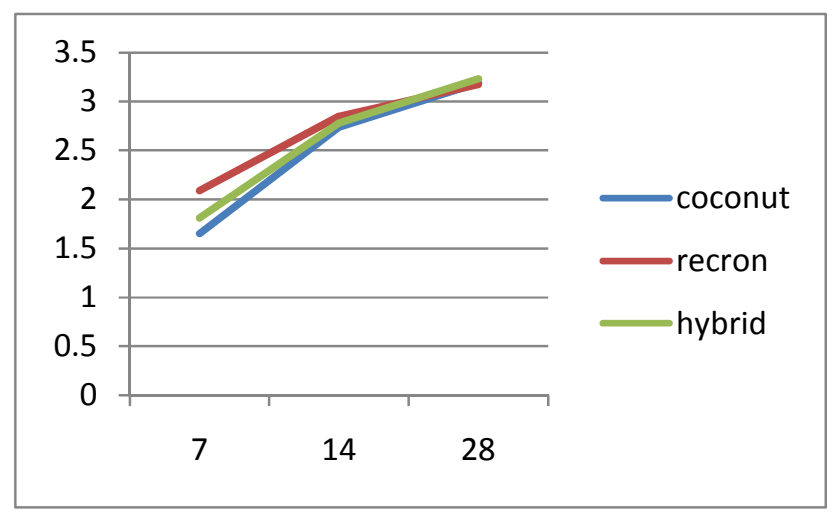

Fig 5 Split tensile strength of $1 \%$ mixed coconut, recron \& hybrid fibre

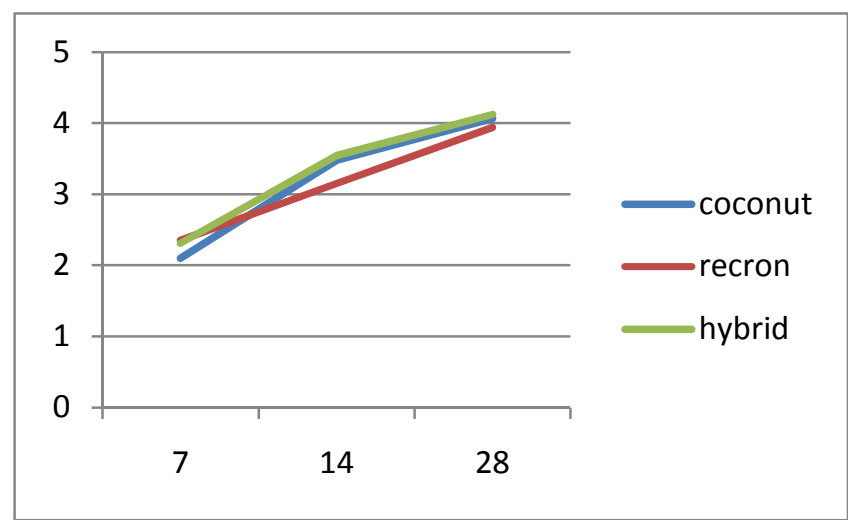

Fig 6 Flexural strength of $1 \%$ mixed coconut, recron \& hybrid fibre

\section{CONCLUSION}

Based on the results obtained in the present study and the discussion of the following conclusions are made:

- $\quad$ Compressive strength test are carried on FRC cubes with varying fibre quantity confirms that the maximum tensile strength is attained when the fibre quantity is $1 \%$ for coconut fibre and $1 \%$ for recron fibre

- Split tensile strength test are carried on FRC cylinders with varying fibre quantity confirms that the maximum tensile strength is attained when the fibre quantity is $1 \%$ for coconut fibre and $1 \%$ for recron fibre

- Flexural tensile strength test are carried on FRC beams with varying fibre quantity confirms that the maximum tensile strength is attained when the fibre quantity is $1 \%$ for coconut fibre and $1 \%$ for recron fibre

- Addition of recron fibre and coconut fibre into PCC increased the split tensile strength of concrete upto 1.36 times and 1.55 times

\section{ACKNOWLEDGEMENTS}

First and foremost I thank the Almighty, who has given me the strength to complete this task. Thereafter I would like to express my sincere gratitude and appreciation to the generosity of the following people who contributed to the success of this study.

- $\quad$ My guide, Professor.S.Anandh for his continuous professional guidance in keeping me focused on the research topic, for his on-going support and motivation throughout the study.

\section{REFERENCES}

[1]. Ahmed.L and A.Ansellet (2010), "efficiency of fiber in concrete".cement and concrete research , pages 1031_1036

[2]. Chaudari P(2006), "Dramix artificial fibres for SFRS and SFRC", The Indain Concrete Journal , Page No.939

[3]. IS:456 (2000)," Plain and Reinforced Concrete Code of Practise"

[4]. IS:1893 Part 1(2002), "Criteria for earthquake resistant design of structure" 


\section{BIOGRAPHIES}

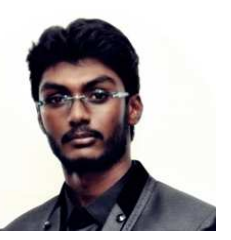

Harish Kumar, PG Student Department of

Civil Engineering, SRM University,

Katangulathur, Chennai

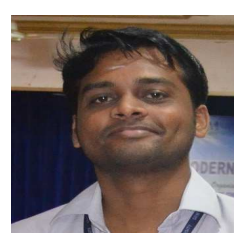

Anandh.S, Assistant Professor,

Department of Civil Engineering, SRM

University, Katangulathur, Chennai 